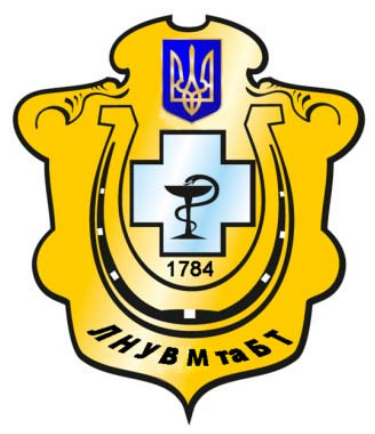

Науковий вісник Львівського національного університету ветеринарної медицини та біотехнологій імені С.3. Гжицького

Scientific Messenger of Lviv National University of Veterinary Medicine and Biotechnologies named after S.Z. Gzhytskyj

doi:10.15421/nvlvet7305

ISSN 2518-7554 print

ISSN 2518-1327 online

$\underline{\text { http://nvlvet.com.ua/ }}$

\title{
The use of GnRH agonist for supression of cats reproductive function
}

\author{
A.I. Vasetska, A.A. Mass \\ anastasiyavas90@gmail.com \\ Lugansk National Agrarian University, \\ st Alchevskih, 44, Kharkiv, 61002, Ukraine
}

The article presents the results concerning the duration of GnRH agonist deslorelin «Suprelorin» 4.7 mg using in cats prepubertal and pubertal age. Experiments conducted on pedigree and non-pedigree cats and lasting for 2.5 years. For research was formed three groups $(n=10)$, age from 3 months to 3 years. The first group was the control animals, they flowed naturally estrus cycle, they received any drugs and have no contact with male. The estrus cycle of the control group of animals observed an average six times within one year, three times in spring and autumn, which is the norm for this type of animal. For 30 months (2.5 years) observation cats from the control group showed excitement stage of estrus cycle an average 15 times.

Animals from the second group, age 3-6 months, which has not have the first estrus (prepubertal) was placed subcutaneous implant «Suprelorin» $4.7 \mathrm{mg}$. In the third group were cats from 7 months to 3 years which have experienced one or more estrus cycles (pubertal). The animals were implanted implant «Suprelorin» $4.7 \mathrm{mg}$ immediately after the last estrus.

In the second group of animals (prepubertal), excitement stage of reproductive cycle manifested through 480-1567 days after implant implanted and the average duration of the reproductive cycle was 920 days (30 months). A few cats from this group were found changes in the reproductive system such as: uneven structure of the endometrium, reducing the size of the ovaries, ovarian cysts after ovariohysterectomy.

Cats from the third group (pubertal) excitement stage of reproductive cycle manifested after 120 to 730 days after implanted the GnRH implant and the average duration of the reproductive cycle was 379 days (approximately 13 months). A few cats from this group, after ovariohysterectomy, observed changes in the reproductive system such as: endometrial hyperplasia, uneven structure and porosity consistency endometrial, ovarian cyst.

Key words: cat, agonist GnRH, implant, implantation, pubertal, prepubertal, sexual cycle, step excitation of the sexual cycle.

\section{Використання агоністу ГнРГ для супресії репродуктивної функції у кішок}

\author{
А.I. Васецька, А.О. Масс \\ anastasiyavas90@gmail.com \\ Луганський начіональний аграрний університет, \\ вул. Алчевських 44, м. Харків, 61002, Україна
}

\begin{abstract}
У статті представлені результати стосовно тривалості дії агоністу ГнРГ деслореліну «Супрелорін» 4,7 мг при використанні кішкам препубертатного і пубертатного віку. Досліди проводились на породистих та безпорідних кішках протягом 2,5 років. Для досліджень було сформовано три групи кішок віком від 3 місяців до 3 років по 10 тварин у кожній. Перша група тварин - контрольна, статевий цикл у них протікав природньо, лікарські препарати їм не задавали, контакту з самием не було. У кішок контрольної групи статевий ичкл спостерігався в середньому шість раз впродовж одного року, по три рази в весняний та осінній періоди, що є нормою для даного виду тварин. 3 а 30 місяців (2,5 років) спостереження кішки контрольної групи проявляли стадію збудження статевого ииклу в середньому 15 разів.

Тваринам другої групи, віком 3-6 місяиів (препубертатні), до першої тічки було поставлено підшкірний імплант "Супрелорін» 4,7 мг. В третій групі були кішки від 7 місяиів до 3 років (пубертатні), у яких наступила статева зрілість та
\end{abstract}

\section{Citation:}

Vasetska, A.I., Mass, A.A. (2017). The use of GnRH agonist for supression of cats reproductive function. Scientific Messenger LNUVMBT named after S.Z. Gzhytskyj, 19(73), 25-27. 
спостерігався один і більше статевих ииклів. Тваринам був підикірно вживлений імплант «Супрелорін» 4,7 мг одразу після закінчення останньої тічки.

У тварин другої групи (препубертатні), стадія збудження статевого иуиклу проявлялась через $480-1567$ днів після вживлення імпланту і в середньому супресія статевого изилу становила 920 днів (більше 30 місяців). У декількох кішок, цієї групи, після проведення оваріогістеректомії були виявлені зміни в статевій системі такі як нерівномірність структури ендометрію, зменшення розмірів яєчників, кіста яєчників.

У кішок третьої групи (пубертатні) стадія збудження статевого циклу настала через 120 до 730 днів після вживлення імпланту $і$ в середньому супресія статевого ичиклу становила 379 днів (приблизно 13 місяців). У декількох кішок, иієі групи, після проведення оваріогістеректомії спостерігались порушення у статевій системі такі як гіперплазія ендометрію, нерівномірність структури та пористість ендометрію, кіста яєчників.

Ключові слова: кішка, агоніст ГнРГ, імплант, вживлення, препубертантні, пубертатні, статевий цикл, стадія збудження статевого цүиклу.

\title{
Использование агониста ГнРГ для супрессии репродуктивной функции у кошек
}

\author{
А.И. Васецкая, А.А. Масс \\ anastasiyavas90@gmail.com \\ Луганский наииональный аграрный університет, \\ ул. Алчевских 44, г. Харьков, 61002, Украина
}

В статье представлены результаты по продолжительности действия агониста ГнРГ деслорелина «Супрелорин» 4,7 мг при использовании кошкам препубертатного и пубертатного возраста. Опыты проводились на породистых и беспородных кошках течение 2,5 лет. Для исследований были сформированы три группы кошек по 10 животных в каждой возрастом от 3 месяиев до 3 лет. Первая группа животных была контрольной, половой цикл у них протекал естественно, лекарственные препараты им не задавали, контакта с самиом не было. У кошек контрольной группы половой иикл наблюдался в среднем шесть раз в течение одного года, по три раза в весенний и осенний период, что является нормой для данного вида животных. За 30 месячев (2,5 года) наблюдения кошки контрольной группь проявляли стадию возбуждения полового иикла в среднем 15 раз.

Животным второй группы в возрасте 3-6 месяцев, до наступления первой течки (препубертатные), был поставлен подкожный имплант «Супрелорин» 4,7 мг. В третьей группе были половозрелые кошки от 7 месяцев до 3 лет, у которых наблюдался один и более половых цииклов (пубертатные). Животным был подкожно вживлен имплант «Супрелорин» 4,7 мг сразу после окончания последней течки.

У животных второй группы (препубертатные), стадия возбуждения полового ичикла проявлялась через 480-1567 дней после вживления импланта и в среднем продолжительность полового ичикла составила 920 дней (более 30 месяцев). У нескольких кошек, этой группы, после проведения овариогистерэктомии были обнаружены изменения в половой системе: неравномерность структуры эндометрия, уменьшение размеров яичников, киста яичников.

У кошек третьей группы (пубертатные) стадия возбуждения полового иикла проявлялась через 120 до 730 дней после вживления импланта и в среднем продолжительность полового иикла составила 379 дней (примерно 13 месяиев). У нескольких кошек, этой группы, после проведения овариогистерэктомии наблюдались нарушения в половой системе такие как гиперплазия эндометрия, неравномерность структуры и пористость эндометрия, киста яичников.

Ключевые слова: кошка, агонист ГнРГ, имплант, вживление препубертантные, пубертатные, половой цикл, стадия возбуждения полового цикла.

\section{Introduction}

A potent agonist of gonadotropin-releasing hormone $(\mathrm{GnRH})$ deslorelin is becoming more and more common in the practice of small animals reproduction and is available in many countries. It is represented as a subcutaneous implant («Suprelorin»), which is slowly released the low dose of hormone in animal's organism a long period of time (Fontaine and Fontbonne, 2011; Walter et al., 2011).

The action of GnRH antagonists completely focused on blocking and inhibiting GnRH receptor-induced, resulting in an immediate drop in the secretion of FSH and LH. In contrast to this, GnRH agonists, GnRH receptors are activated, causing hypersecretion of circulating $\mathrm{FSH}$ and $\mathrm{LH}$, which are accompanied by increased concentrations of sex steroid hormones, called «flare effect». But after the initial stimulation effect in excess of the dose or low long-term doses of GnRH agonists, resulting in a suppression of pituitary gonadotropin receptor regulation and suppression of $\mathrm{LH}$ and FSH release with subsequent suppression of reproductive function of animals (Corrada et al., 2006; Trigg et al., 2006).

GnRH agonist deslorelin («Suprelorin») has been actively used in the leading veterinary clinics Ukraine, but not sufficiently studied the duration of the implant «Suprelorin» $4.7 \mathrm{mg}$ to inhibit reproductive function pubertal and prepubertal cats.

\section{Materials and methods}

Experiments conducted on pedigree and non-pedigree cats during 2.5 years. The owners of the animals that was treated in Kharkiv clinics wants to prevent unwanted displays of estrous behavior in animals by putting the 
implant «Suprelorin» $4.7 \mathrm{mg}$. For research was formed three groups of cats $(n=10)$, age from 3 months to 3 years. The first group was the control, the sexual cycle of animals flowed naturally, they receive any drugs, and had no contacts with a male.

Animals of the second group, aged 3-6 months, which have not been at the first estrus cycle (prepubertal) was implanted subcutaneous implant «Suprelorin» $4.7 \mathrm{mg}$. In the third group were cats aged from 7 months to 3 years which have one or more estrus cycles (pubertal). The animals were implanted subcutaneous implant immediately after the end of the last estrus.

After the research several animals from the second and third group was conducted ovariohysterectomy.

\section{Results and discussion}

Cat's sexual cycle of the control group experienced an average of six times within one year, three times in spring and autumn, which is the norm for this type of animal. For 30 months (2.5 years) observation cat control group showed excitement stage of estrus cycle an average of 15 times.

In the second group of animals (prepubertal), stage of sexual cycle excitement manifested through 480-1567 days after implantation of the implant and the average duration of the sexual cycle was 920 days (30 months). A few cats from that group, after the end of the implant action, were conducted ovariohysterectomy and were found in the reproductive system changes such as: an uneven structure of the endometrium, ovarian cysts and reducing the size of the ovaries.

Cats from the third group (pubertal) excitation stage of sexual cycle manifested by 120-730 days after implanted the subcutaneous implant and the average duration of estrus cycle was 379 days (approximately 13 months). A few cats from this group, after ovariohysterectomy, observed infringements in the reproductive system such as endometrial hyperplasia, uneven structure and porosity endometrium and ovarian cyst.

The duration of estrus cycle in cats experimental groups

\begin{tabular}{|c|c|c|c|c|c|c|c|c|}
\hline \multirow{11}{*}{ 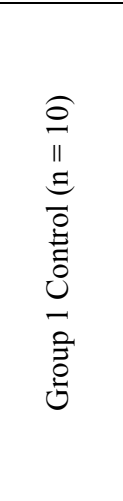 } & № & $\begin{array}{l}\text { Duration of } \\
\text { estrus cycle }\end{array}$ & \multirow{11}{*}{ 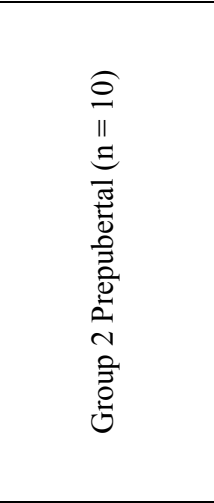 } & № & $\begin{array}{c}\text { Duration of } \\
\text { estrus cycle } \\
\text { (days) }\end{array}$ & \multirow{11}{*}{ 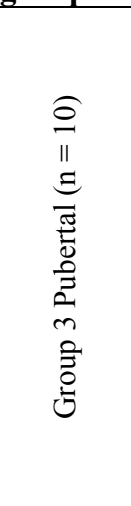 } & № & $\begin{array}{c}\text { Duration of } \\
\text { estrus cycle } \\
\text { (days) }\end{array}$ \\
\hline & 1 & \multirow{10}{*}{$\begin{array}{l}3 \text { times sea- } \\
\text { sonal cycling }\end{array}$} & & 1 & 728 & & 1 & 165 \\
\hline & 2 & & & 2 & 670 & & 2 & 188 \\
\hline & 3 & & & 3 & 856 & & 3 & 365 \\
\hline & 4 & & & 4 & 923 & & 4 & 245 \\
\hline & 5 & & & 5 & 1245 & & 5 & 300 \\
\hline & 6 & & & 6 & 1567 & & 6 & 120 \\
\hline & 7 & & & 7 & 1025 & & 7 & 456 \\
\hline & 8 & & & 8 & 548 & & 8 & 632 \\
\hline & 9 & & & 9 & 1160 & & 9 & 590 \\
\hline & 10 & & & 10 & 480 & & 10 & 730 \\
\hline $\begin{array}{l}\text { Average } \\
\text { duration } \\
\text { (days) }\end{array}$ & & times a year & $\begin{array}{l}\text { Average dura- } \\
\text { tion (days) }\end{array}$ & & 920 & $\begin{array}{c}\text { Average } \\
\text { duration } \\
\text { (days) }\end{array}$ & & 379 \\
\hline
\end{tabular}

\section{Conclusions}

1. Stage excitement of the estrus cycle in cats of the control group manifested from 4 to 9 times, on average 6 times per year.

2. The implantation of a subcutaneous implant «Suprelorin» $4.7 \mathrm{mg}$ cats prepubertal age remove manifestation of excitement stage of estrus cycle an average of 30 months significantly compared with the control group ( $\mathrm{P}$ $<0.001)$.

3. The third group of mature cats excitement stage of estrus cycle advancing an average of 13 months after implantation of the implant that significantly compared with the control group $(\mathrm{P}<0.001)$.

Prospects for further research. Further research is planned to carry out the influence of GnRH agonist deslorelin «Suprelorin» $4.7 \mathrm{mg}$ to the uterus, ovaries, mammary gland and the adrenal glands of females and determine their future ability to fertilize the end of using the drug.

\section{References}

Fontaine, E., Fontbonne, A. (2011). Clinical use of GnRH agonists in canine and feline species. Reprod Dom Anim. 46, 344-353.

Walter, B., Otzdorff, C., Brugger, N., Braun, J. (2011). Estrus induction in queens with the GnRH-agonist implant containing $4.7 \mathrm{mg}$ Deslorelin. Theriogenology. 75(6), 1125-1129.

Corrada, Y., Hermo, G., Johnson, C., Trigg, T., Gobello, C. (2006). Short-term progestin treatment prevent estrus induction by a GnRH agonist implant in anestrous queens. Theriogenology. 65, 366-373.

Trigg, T., Doyle, A., Walsh, J., Swangchan-Uthai, T. (2006). A review of the advances in the use of the $\mathrm{GnRH}$ agonist deslorelin in the control of reproduction. Theriogenology. 66, 1507-1512.

Стаття надійшла до редакиії 7.03.2017 